\title{
Analysis of Ownership and Stock Composition of Vocational Business Enterprises (BUMDES) and Its Impact on "Omset" of Business Owned Enterprises
}

\author{
Arifin Lubis \\ Accounting Departemen \\ Economic \& Bussiness Faculty \\ Universitas Sumatera Utara \\ arifin@usu.ac.id
}

\author{
Iskandar Muda \\ Accounting Departemen \\ Economic \& Bussiness Faculty \\ Universitas Sumatera Utara \\ iskandar1@usu.ac.id
}

\author{
Rustam \\ Accounting Departemen \\ Economic \& Bussiness Faculty \\ Universitas Sumatera Utara \\ rustam@usu.ac.id
}

\begin{abstract}
The purpose of this research is to know the ownership and composition of shares of village-owned enterprises and their impact on the turnover of business entities. The type of this research is descriptive quantitative with the population of 102 Village Owned Enterprises in Asahan Regency. The selected sample is 102 business entities. The analytical tool of this research is with Multiple Regression with of Smart-PLS software. The results show ownership and composition of shares of village-owned enterprises not significantto the turnover of business entities.
\end{abstract}

Keywords-ownership; share composition; turnover of business entity and Village Owned Enterprise

\section{INTRODUCTION}

Establishment and management of Village Owned Enterprises is a manifestation of the management of the village's productive economy undertaken in a Cooperative, Participatory, Emancipative, Transparant, Accountable and Sustain manner [1]. Therefore, serious efforts are needed to make the management of Village Owned Enterprise can run independently, effectively, efficiently and professionally[17], [18],[22],[23],[32]\&[33].

BUMDes are founded on community initiatives based on potentials that can be developed using local resources and there is market demand. In other words, the establishment of BUMDes is not an instructional package coming from the Government, provincial government, or district government. If that is so worsened, BUMDes will run not as mandated by the law[3],[4],[5]\&[6]. The task and role of the Government are to socialize and raise awareness to the village community through the provincial and district governments on the importance of BUMDes for the improvement of the people's welfare. Through the village government, the community is motivated, awakened and prepared to build its own life. The Government facilitates in the form of education and training and other fulfillment that can facilitate the establishment of BUMDes. Furthermore, the operational mechanism is left entirely to the village community[7],[9]\&[13]. To that end, the village community needs to be prepared in advance in order to receive new ideas about economic institutions that have two functions namely social and commercial.
In order to achieve the objective of BUMDes is done by fulfilling the needs (Productive and Consumptive) of the community through the service of goods and services that managed by the community and village government. This institution is also required to provide services to nonmembers (parties outside the Village) by placing prices and services according to market standards. This means that there is a mutually agreed institutional mechanism, so as not to cause a rural economic disorder caused by BUMDes effort. After the birth of the Village Law, two entities were born in the village, namely the Village Government and the Village Owned Enterprise. BUMDES is a business entity, so it has business activities and profit-seeking purposes. However, in the course of BUMDES, it is different from the purely private business, because BUMDES is an extension of the village government in carrying out its functions, mainly in terms of providing eligibility to the village community and empowering the village community. Therefore, BUMDES can not solely seek profit. BUMDES is established then there are two entities in the village, namely the Village Government and the village business unit that is BUMDES. Funds originating from the Village Government may be included with BUMDES, as they are separate entities/entities. The village treasury put into BUMDES is a separate village government treasure.

Establish and develop integrated approaches to community and village development and empowerment that can provide comfort, social and economic prosperity[34],[35]\&[36]. Improving the performance of the institution and social capital rural areas that can grow culture and culture while strengthening social cohesion, encouraging local democratization movement[41], [42]\&[46]. Increasing the empowerment of rural communities in maximizing maximum self-sufficiency for the prosperity and wellbeing of the villagers themselves. Growth and rural development from social and economic aspects characterized by trade and services activities[1],[43],[44]\&[45].Such as markets, small industries/houses, and other service centers. The development of economic activity is capable of generating trickle-down effect towards the village of being and lagging around it. 


\section{METHOD}

This study usessecondarydata.The hypothesis was tested by using Structural Equation Modeling with SMART PLS software. The data analysis technique in this research employed Structural Equation Modeling (SEM). SEM is a set of statistical techniques allowing testing of a series of relationships simultaneously. Furthermore, in the data processing, the writer used the aid from software SMART-PLS Structural Equation Modeling, which was one of the multivariate analyses capable of analyzing the variable relationships in complex manner [8], [10], [11]\&[12]. The hypotheses were tested using Structural Equation Modeling (SEM) with Smart-PLS software tools. The equation is formed as follows:

$$
\begin{array}{ll}
\mathrm{Y}=\alpha+\mathrm{b} 1 \mathrm{X} 1 & +\mathrm{b} 2 \mathrm{X} 2++\mathrm{b} 3 \mathrm{X} 3+\mathrm{e} \\
\mathrm{X} 1 & =\text { Ownership } \\
\mathrm{X} 2 & =\text { Composition of Shares } \\
\mathrm{Y} & =\text { Turnover of Business Entities } \\
\mathrm{b} 1, \ldots \mathrm{b} 3 & =\text { Coefficient } \\
\alpha & =\text { Constant } \\
\mathrm{e} & =\text { Error }
\end{array}
$$

This phase is done to test the suitability of the model to evaluate the goodness-of-fit index[19],[20],[24],[25]\&[26]. Analysis using SEM requires some suitability index to measure the correctness of data and models.

\section{RESULT}

\section{A. Result}

Inner model evaluation through the bootstrapping menu also generates $\mathrm{T}$-statistics values that will be used to test the hypothesis. The criteria are T-statistic $>1.66$ (value $\alpha=5 \%$, one tail). The result of $\mathrm{T}$-statistics value in the table path coefficients is presented in the following figure:

Figure 1. Overall Model with Coefficient

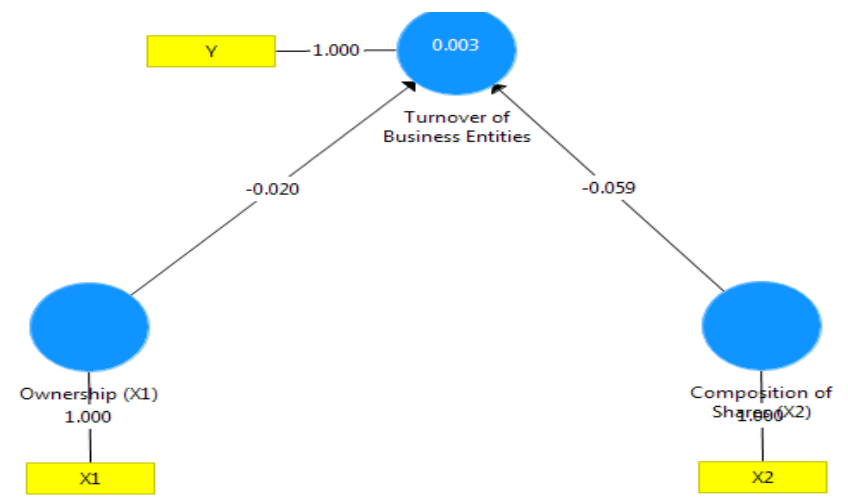

The effect test can be seen in the following table:

Table 1. The result of bootstrapping

\begin{tabular}{|l|r|r|r|r|r|}
\hline & $\begin{array}{c}\text { Original } \\
\text { Sample } \\
(\mathrm{O})\end{array}$ & $\begin{array}{c}\text { Sample } \\
\text { Mean } \\
(\mathrm{M})\end{array}$ & $\begin{array}{c}\text { Standard } \\
\text { Deviation } \\
\text { (STDEV) }\end{array}$ & $\begin{array}{c}\mathrm{T} \\
\text { Statistics }\end{array}$ & $\begin{array}{c}\mathrm{P} \\
\text { Values }\end{array}$ \\
\hline $\begin{array}{l}\text { Composition of Shares (X2) -> } \\
\text { Turnover of Business Entities }\end{array}$ & $-0,059$ & $-0,054$ & 0,074 & 0,796 & 0,427 \\
\hline $\begin{array}{l}\text { Ownership (X1) -> Turnover } \\
\text { of Business Entities }\end{array}$ & $-0,020$ & $-0,022$ & 0,125 & 0,159 & 0,874 \\
\hline
\end{tabular}

These results show that the Ownership and Composition of Shares variables have no significant effect on the Turnover of Business Entities BUMDEs. This is because Turnover of Business Entities BUMDEs is determined by other factors not represented by these variables.

Figure 2. Ownership (X1)

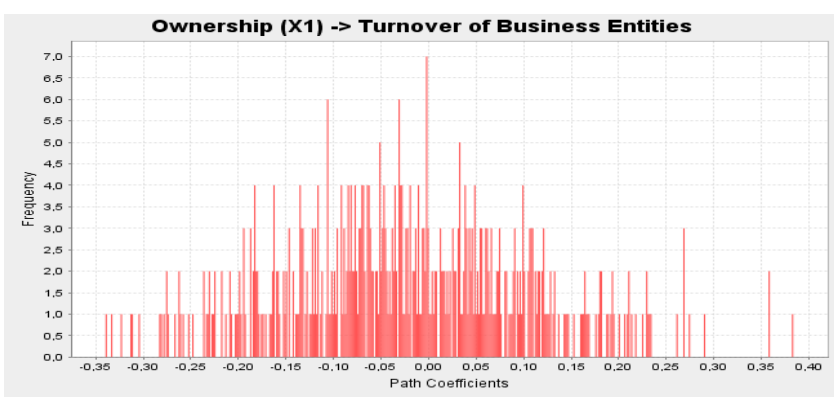

Source: PLS Output (2017)

Figure 3. Composition of Shares

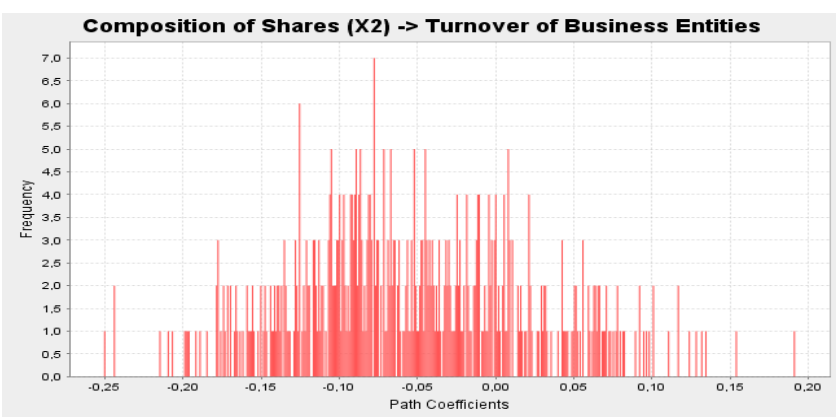

Source: PLS Output (2017)

Based on the above table the indirect effect produces coefficient of 0.005 , smaller than 1.66 [14],[16]\&[21], then the decision of hypothesis testing reject $\mathrm{HO}$ and accept the hypothesis Ha [27], [28],[29]\&[30]In addition to hypothesis testing through the bootstrapping menu that produces $\mathrm{T}$ statistics, inner model evaluation is also done by reviewing the R-Square value [31],[40]\&[47]. The R-square value generated from the inner model evaluation is presented in the following table:

Table 3. R-Square Value

\begin{tabular}{|l|c|c|}
\hline & R Square & $\begin{array}{c}\text { R Square } \\
\text { Adjusted }\end{array}$ \\
\hline $\begin{array}{l}\text { Turnover of Business } \\
\text { Entities }\end{array}$ & 0,003 & 0,017 \\
\hline
\end{tabular}


Figure 4. F Square

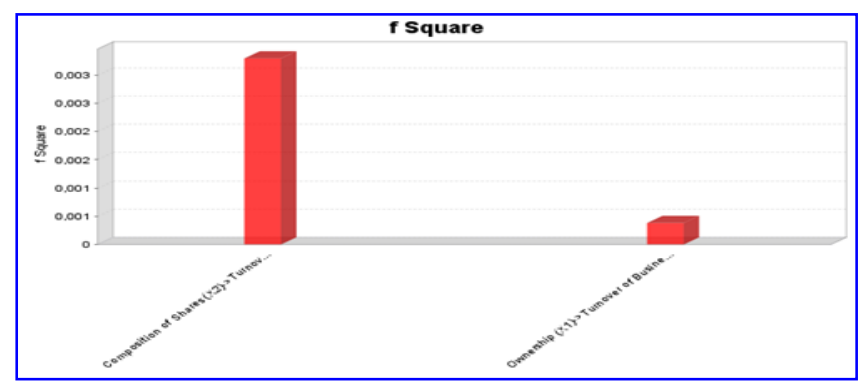

Source: PLS Output. (2017)
BUMDES has SK and is inaugurated[2]. Before the execution is done, the BUMDES participation must be agreed in MUSDES and published PERDES by itself. So there is a PERDES forming BUMDES, and there PERDES inclusion BUMDES. After it has been done, the Minutes of inclusion are recorded in the bookkeeping of the Village Government and BUMDES.

\section{CONCLUSIONS}

The results show ownership and composition of shares of village-owned enterprises not significantto the turnover of business entities.

\section{REFERENCES}

\section{B. Discussion}

IThe village is a socio-political entity that has unique characteristics in the formal structure of the institutional state of the Republic of Indonesia. [37],[38]\&[39], on the Village becomes an estuary for the realization of independence or autonomy of his government. Autonomy that is not of autonomy, but must lead to participatory democracy in the overall economic development of the village. It is hoped that this law will be able to eliminate various problems in the village, such as social, culture and economy. Empowerment processes that emphasize the process of providing the ability to the community to become empowered, encourage or motivate individuals to have the ability or empowerment to determine the choice of life. It is further said that empowerment should be aimed at the group or layers of society left behind, in a way to be continuously built mentally and morally to grow a new spirit with high confidence, Transactions occur when there are two parties that exchange benefits. The existence of BUMDES institution allows the Village Government to conduct transactions with BUMDES legally and convincingly. This has been regulated in the Village Law and its derivative regulations. First discuss three transactions that can occur between the Village Government and BUMDES namely participation, loans and assistance. Inclusion means that the Village Government makes long-term investments by including a sum of money or other assets to form or add capital BUMDES. The village government can also provide assistance or loans to BUMDES. The difference between Participation and Loan is if Loan is no time limit for return of principal and interest/profit sharing calculation. For assistance or grants it is usually in the form of equipment, training and other facilities. If BUMDES receives funds, assets or facilities from the village it is necessary to pay attention to the contract whether it is an investment, loan or assistance.If the chosen contract is an accompaniment then there are several mechanisms and administration that must be prepared. Investment in BUMDES entered into Financing account. The deal agreement is a longterm investment rather than a spending, then it is entered in a finance account[2].

In order to be included in the APBDes, the previous mechanism was Musrenbangdus, Murenbangdes, RPJMdes, RKP and then entered APBDes.BUMDES formed through the Village deliberation and set forth in the Village Rules and the establishment of BUMDES has been issued and the Board of

[1] Alam, M. "Level and Composition of Capital in Irrigated Agriculture of Bangladesh: Evidence from Tubewell Irrigated Villages of Comilla and Rajshahi”. The Bangladesh Development Studies, (1984). pp.59-106.

[2] Azlina, Nur., Amir Hasan, Desmiyawati\&Muda, I. "The Effectiveness of Village Fund Management (Case Study at Villages in Coastal Areas in Riau)". International Journal of Economic Research. Vol.14 Issue 12. (2017). pp.325-336.

[3] Bowles, P., \& Dong, X. Y. "Enterprise ownership, enterprise organization, and worker attitudes in Chinese rural industry: some new evidence". Cambridge Journal of Economics, 23(1), (1999). pp.1-20.

[4] Buchanan, D. H. Development of capitalistic enterprise in India. (2013). Routledge.

[5] Chang, C., \& Wang, Y. The nature of the township-village enterprise. Journal of Comparative Economics, 19(3), (1994).pp.434452.

[6] Clegg, J. Multi-stakeholder cooperation in China: changing ownership and management of rural enterprises. Village Inc., Chinese Rural Society in the 1990s, Curzon, London, (1998). pp.66-82.

[7] Cooke, F. Vocational and enterprise training in China: Policy, practice and prospect. Journal of the Asia Pacific Economy, 10(1), (2005).pp.2655.

[8] Dalimunthe., D.M.J.,Fadli, and Muda, I. The application of performance measurement system model using Malcolm Baldrige Model (MBM) to support Civil State Apparatus Law (ASN) number 5 of 2014 in Indonesia. International Journal of Applied Business and Economic Research. Vol.14 Issue 11. (2016). pp.7397-7407.

[9] Demsetz, H. Toward a theory of property rights II: The competition between private and collective ownership. The Journal of Legal Studies, 31(S2), (2002). pp.S653-S672.

[10] Erlina., Ari Saputra\&Muda, I. Antecedents of Budget Quality Empirical Evidence from Provincial Government In Indonesia. International Journal of Economic Research. Vol. 14 Issue 12. (2017). pp.301-312.

[11] Erlina., Ari Saputra\&Muda, I. The Analysis of the Influencing Factors of Budget Absorption. International Journal of Economic Research. Vol. 14 Issue 12. (2017). pp.287-300.

[12] Erlina.,ConflictofInterestImpact: FactorsAnalysisAffectingtheBudgetQualityinMedanCity. International Journal of Economic Research. Vol.14 Issue 12. (2017). pp.135-145.

[13] Farooquee, N. A., \&Nautiyal, A. Livestock ownership patterns among transhumanists in high-altitude villages of the central Himalayas. Nomadic Peoples, (1996). pp.87-95.

[14] Gusnardi.,Riadi, R.M., and Muda, I. Competency mapping and analysis of students competency based on economics subject national examination and its alternative solutions in state high schools at Pekanbaru. International Journal of Economic Research. Vol.3 Issue 5. (2016). pp.2133-2148.

[15] Handoko, Bagus.,Sunaryo\&Muda, I. Difference Analysis of Consumer Perception of Motorcycle Product Quality. International Journal of Economic Research. Vol. 14 Issue 12. (2017). pp.363-379. 
[16] Hasan., Amir, Gusnardi\&Muda, I.Analysis of Taxpayers and Understanding Awareness Increase in Compliance with Taxpayers Individual Taxpayers. International Journal of Economic Research. Vol.14 Issue 12. (2017). pp. 75-90.

[17] Jaitner, J., Sowe, J., Secka-Njie, E., \&Dempfle, L. Ownership pattern and management practices of small ruminants in The Gambiaimplications for a breeding programme. Small ruminant research, 40(2), (2001). pp.101-108.

[18] Kung, J. K. S. “The structure and evolution of property rights in China's village enterprises": The case of Wuxi county. (1997). In Paper originally presented at the Conference on Property Rights in Transitional Economies: Research Insights from China, held at the Hong Kong University of Science and Technology.

[19] Lubis., A.,Torong, Z.B., and Muda, I. "The urgency of implementing balanced scorecard system on local government in North Sumatra Indonesia".International Journal of Applied Business and Economic Research. Vol.14 Issue 11. (2016). pp.7575-7590.

[20] Lubis., A.F., Lubis, T.A., and Muda, I. "The role of Enterprise Resource Plan (ERP) configuration to the timeliness of the financial statement presentation". International Journal of Applied Business and Economic Research. Vol.14 Issue 11. (2016). pp.7591-7608.

[21] Lutfi., M.,Nazwar, C., and Muda, I. "Effects of investment opportunity set, company size and real activity manipulation of issuers in Indonesia Stock Exchange on stock price in Indonesia". International Journal of Economic Research. Vol.13 Issue 5. (2016). pp.2149-2161.

[22] Lyne, I. "Social enterprise and the everydayness of precarious Indigenous Cambodian villagers". Critical Perspectives on Entrepreneurship: Challenging Dominant Discourses, (2017). 36.

[23] Mood, M. S. "Opportunists, predators, and rogues: the role of local state relations in shaping Chinese rural development."Journal of Agrarian Change, 5(2), (2005).pp.217-250.

[24] Muda., I and AbykusnoDharsuky. "Impact of Region Financial Information System (SIKD) Quality, Role Ambiguity And Training on Precision of Financial Statement of Local Government Presentation In North Sumatra". International Journal of Applied Business and Economic Research, Vol.13 Issue 6. (2015). pp.4283-4304.

[25] Muda., I, DeniYuwiliaWardani, Erlina, AzharMaksum, Ade FatmaLubis and Rina Bukit. "The Influence of Human Resources Competency and The Use of Information Technology on The Quality of Local Government Financial Report with Regional Accounting System as an Intervening". Journal of Theoretical and Applied Information Technology. Vol.95 Issue 17. (2017). pp.1432-1451.

[26] Muda., I, Dharsuky. A., Siregar, H.S., and Sadalia, I. "combined loading and Cross-dimensional loadings timeliness of presentation of financial statements of local government". IOP Conference Series: Materials Science and Engineering. Bandung, (2017). 180. doi: 10.1088/1757899X/180/1/012099.

[27] Muda., I, Marlon Sihombing, ErniJumilawati and AbikusnoDharsuky. "Critical Success Factors Downstream Palm Oil Based Small And Medium Enterprises (SME) In Indonesia”. International Journal of Economic Research. Vol.13 Issue 8. (2016). pp. 3531-3538.

[28] Muda., I., Rafiki, A., \&Harahap, M. R. "Factors Influencing Employees' Performance: A Study on the Islamic Banks in Indonesia". International Journal of Business and Social Science, Vol.5Issue 2. (2014). pp. 73-80.

[29] Muda., I.,Dharsuky, A.,Sadalia, I., and Siregar, H.S. "Impact of capital investments and cash dividend policy on Regional Development Bank (BPD) PT. Bank Sumut to the district own source revenue and economic growth". International Journal of Applied Business and Economic Research. Vol.14 Issue 11. (2016). pp.7863-7880.

[30] Muda.,Iskandar. "The Effect of Supervisory Board Cross-Membership and Supervisory Board Members' Expertise to The Disclosure of Supervisory Board's Report: Empirical Evidence From Indonesia". European Research Studies Journal. Vol.XX Issue 3A. (2017). pp.702716.

[31] Nasir, Azwir.,YesiMutiaBasri, Kamaliah\&Muda, I. "Effectiveness of Potential Tax Region as the Real Local Revenue Sources in Riau Coastal Area". International Journal of Economic Research. Vol.14 Issue 12. (2017). pp.313-324.

[32] Pan, J. W., \& Zhou, X. R. A."Study of the Villagers' Rights of Autonomy and Their Rights of Economic Autonomy". Journal of South China Normal University (Social Science Edition), 4(6) (2003).pp.45-56.

[33] Pan, S., \& Park, A. Collective ownership and privatization of China's village enterprises. (1998).

[34] Paz, M. "Moldavian Villagers OfLapushna And Tartaul De Salcie About De-Collectivization". EtnografiaPolska, 1(51), (2007). pp.149-170.

[35] Peng, Y. "Chinese villages and townships as industrial corporations: ownership, governance, and market discipline". American Journal of Sociology, 106(5). (2001). 1338-1370.

[36] Putterman, L. "On the past and future of China's township and villageowned enterprises". World Development, 25(10), (1997).pp.1639-1655.

[37] Republic of Indonesia. Law Number 6 Year 2014 on the Village. Jakarta.

[38] Republic of Indonesia. PP no. 72 Year 2005 on Village. Jakarta.

[39] Republic of Indonesia. UU no. 32 of 2004 on Regional Government. Jakarta.

[40] Sadalia, .Isfenti., Nur Ahmadi Bi Rahamani\&Muda, I. "The Significance of Internet-Based Financial Information Disclosure on Corporates' Shares in Indonesia". International Journal of Economic Research. Vol.14 Issue 12. (2017). pp.337-346.

[41] Smart, A., \& Smart, J. "Local citizenship: welfare reform urban/rural status, and exclusion in China". Environment and Planning A, 33(10), (2001). pp.1853-1869.

[42] Tan, N. Q. "Trends in forest ownership, forest resources tenure and institutional arrangements: are they contributing to better forest management and poverty reduction? A case study from Vietnam". Understanding Forest Tenure in South and Southeast AsiaForestry Policy and Institutions, (2006). pp.355-407.

[43] Unger, J., \& Chan, A. "Inheritors of the boom: private enterprise and the role of local government in a rural south China township". The China Journal, (42), (1999). pp.45-74.

[44] Von Friedeburg, R. Reformation of manners and the social composition of offenders in an East Anglian cloth village: Earls Colne, Essex, 15311642. Journal of British Studies, 29(4), (1990).pp.347-385.

[45] Xiaoshan, Z. "Co-operatives, communities and the state: the recent development of Chinese rural co-operatives in transition". Land Reform, 1(2). (1999). pp.78-89.

[46] Xu, W., \& Tan, K. C. "Reform and the process of economic restructuring in rural China: a case study of Yuhang", Zhejiang. Journal of Rural Studies, 17(2), (2001).pp.165-181.

[47] Yahya.,Idhar., Torong, Z.B., and Muda, I.. "Influence Behavior in Legislature Budget Development of Regions in the Province of Aceh and North Sumatra". International Journal of Economic Research, Vol.14 Issue 8. (2017). pp. 147-159. 